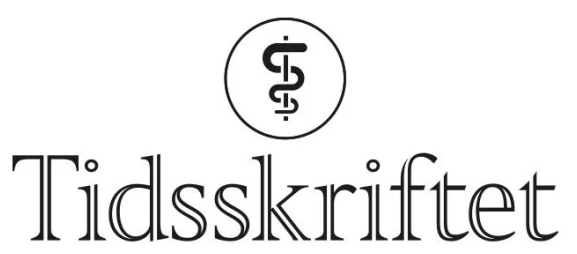

DEN NORSKE LEGEFORENING

\title{
Koronasmitte i førstelinjen
}

\section{LEDER}

\section{MARIUS MYRSTAD}

marium@vestreviken.no

Marius Myrstad er ph.d., spesialist i indremedisin og i geriatri, overlege og forsker ved Medisinsk avdeling, Bærum sykehus.

Forfatteren har fylt ut ICMJE-skjemaet og oppgir ingen interessekonflikter.

\section{Flere enn 5600 ansatte i helse- og omsorgstjenesten ble smittet med SARS-CoV-2 i 2020. Gode helsetjenester er avhengig av at nok ansatte er friske og kan gå på jobb.}

Kunnskap om SARS-CoV-2-smitte blant ansatte i helsetjenestene er viktig av flere årsaker. Ansatte som er smittet, kan smitte både pasienter og kolleger og forårsake lokale utbrudd. Sykefravær på grunn av covid-19 og mange ansatte i karantene kan påvirke pasienttilbudet og øke belastningen for de ansatte som ikke er i karantene.

Molvik, Danielsen og medarbeidere fra Folkehelseinstituttet presenterer i Tidsskriftet insidensen av påvist SARS-CoV-2-smitte blant 382332 ansatte i helse- og omsorgstjenestene i Norge i løpet av 2020 (1). Studien er basert på data fra beredskapsregisteret Beredt C19, som ble opprettet for å fremskaffe kunnskap som kan gi støtte til beslutninger om tiltak for folkehelsen (2 2 . Studien viser at minst 5673 ansatte i helsetjenestene i Norge var smittet med SARS-CoV-2 i løpet av 2020. Det reelle tallet er høyere, blant annet fordi fastleger og andre selvstendig næringsdrivende ikke er inkludert i datasettet, og fordi en del har vært smittet uten å bli testet.

I likhet med internasjonale studier viser den norske studien en høyere forekomst av registrert SARS-CoV-2-smitte blant ansatte i helsetjenestene enn i den øvrige befolkningen (3). Insidensen blant alle ansatte i helsetjenesten i 2020 var 1,48 \%, mens den i samme periode var 1,11\% i resten av den yrkesaktive befolkningen.

Det høye antallet smittede har utvilsomt påvirket de ulike delene av helsetjenestene i Norge. Ansatte på sykehjem og sykehus hadde den høyeste insidensen og de høyeste smittetallene blant de undersøkte tjenestene. Minst 1534 av de smittede var ansatte i sykehjem. Mens sykehusenes kapasitet her til lands har vært utfordret i mindre grad enn man kunne frykte under pandemien, har flere sykehjem hatt dramatiske smitteutbrudd. Sykehjemsbeboere er blant de eldste og skrøpeligste i samfunnet, og flere slike utbrudd har dessverre ført til alvorlig sykdom og dødsfall (4). Flere sykehjem har dessuten hatt store driftsutfordringer på grunn av sykdom og karantene blant ansatte. 
Hvilke deler av befolkningen som bør prioriteres for SARS-CoV-2-vaksinering, diskuteres for fullt, og flere har tatt til orde for at ansatte i helsevesenet burde stått lenger fram i køen. Det høye antallet smittede ansatte, i kombinasjon med de potensielt svært alvorlige konsekvensene av smitteutbrudd i sykehjem, taler for at sykehjemsansatte bør prioriteres for tidlig vaksinering. Data fra beredskapsregisteret kan være til hjelp ved slike beslutninger, og det er prisverdig at disse dataene publiseres fortløpende, slik som i artikkelen til Molvik, Danielsen og medarbeidere.

\section{"I likhet med internasjonale studier viser den norske studien en høyere forekomst av registrert SARS-CoV-2-smitte blant ansatte $i$ helsetjenestene enn i den øvrige befolkningen»}

Men studien etterlater også flere viktige spørsmål. Det skilles ikke mellom smitte på eller utenfor arbeidsplassen, og vi får dermed ikke svar på hvilken risiko ansatte i helsevesenet løper ved å utføre jobben sin. Selv om ambulansepersonell var yrkesgruppen med høyest insidens av SARS-CoV-2-smitte, gir studien ikke klart svar på hvilke yrkesgrupper som er mest utsatt for smitterisiko. Betydningen av pandemien for de ansatte i helsetjenestene har flere fasetter enn det antall smittede kan fortelle oss. Mange har blitt smittet på jobb, og noen har blitt syke. Flere har blitt smittet etter kontakt med covid-19-pasienter, til tross for strenge smitteverntiltak og riktig bruk av beskyttelsesutstyr. Å jobbe med risiko for selv å bli syk, endrede forutsetninger og $\varnothing \mathrm{kt}$ arbeidsbelastning gjennom en pandemi som snart har vart i ett år, er andre faktorer som trolig har påvirket ansattes helse. Forhåpentligvis kan beredskapsregisteret også gi svar på hvor mange ansatte i de norske helsetjenestene som har vært syke med covid-19, og hvor mange som har hatt behov for helsehjelp under den pågående pandemien.

Selv om tilgang til vaksiner og omfattende smitteverntiltak gir håp om en lysere framtid, er det fortsatt ikke utelukket at helsetjenestenes kapasitet kan bli satt på prøve, også i Norge. Derfor er det grunn til å se nærmere på årsakene til de høye smittetallene, ikke minst blant ansatte i sykehjem. De ansattes sosioøkonomiske bakgrunn, andeler av ufaglærte ansatte og ansettelsesforhold ved flere institusjoner samtidig, er eksempler på faktorer som kan tenkes å spille en rolle. Kapasiteten til det norske helsevesenet avhenger blant annet av hvor mange ansatte som til enhver tid er friske og kan gå på jobb. Epidemiologiske data fra koblinger mellom ulike registre, slik som i beredskapsregisteret, kan gi støtte til tiltak som kan redusere helsetjenestenes sårbarhet dersom 2021 skulle by på en ny smittebølge.

\section{LITTERATUR}

1. Molvik M, Danielsen AS, Grøsland M et al. SARS-CoV-2 blant ansatte i helse- og omsorgstjenesten i Norge. Tidsskr Nor Legeforen 2021; 141. doi:10.4045/tidsskr.20.1048. [CrossRef]

2. Folkehelseinstituttet. Beredskapsregisteret for covid-19. https://www.fhi.no/sv/smittsommesykdommer/corona/norsk-beredskapsregister-for-covid-19/ Lest 26.1.2021.

3. Gómez-Ochoa SA, Franco OH, Rojas LZ et al. COVID-19 in health-care workers: A living systematic review and meta-analysis of prevalence, risk factors, clinical characteristics, and outcomes. Am J Epidemiol 2021; 190:187. [PubMed][CrossRef]

4. Kittang BR, Hofacker SV, Solheim SP et al. Utbrudd av covid-19 ved tre sykehjem i Bergen. Tidsskr Nor Legeforen 2020; 140. doi: 10.4045/tidsskr.20.0405. [PubMed][CrossRef]

Publisert: 10. februar 2021. Tidsskr Nor Legeforen. DOI: 10.4045/tidsskr.21.0076 (C) Tidsskrift for Den norske legeforening 2023. Lastet ned fra tidsskriftet.no 26. april 2023. 